\title{
Global impacts of surface ozone changes on crop yields and land use
}

\author{
Clifford Chuwah a, b, c, *, Twan van Noije a, Detlef P. van Vuuren ${ }^{\text {b, d }}{ }^{\text {, Elke Stehfest }}{ }^{\text {b }}$, \\ Wilco Hazeleger ${ }^{\text {a, c }}$ \\ a Royal Netherlands Meteorological Institute, De Bilt, The Netherlands \\ ${ }^{\mathrm{b}}$ Netherlands Environmental Assessment Agency (PBL), Bilthoven, The Netherlands \\ ${ }^{c}$ Wageningen University, Wageningen, The Netherlands \\ d Utrecht University, Department of Geosciences, Utrecht, The Netherlands
}

\section{H I G H L I G H T S}

- We estimate ozone impacts on crop yields using high and low air pollution scenarios.

- Substantial crop losses can be avoided by air pollution control, especially in Asia.

- Climate policies can have co-benefits for crops due to reduced co-emissions.

- Reduced ozone damage will also reduce land use and associated carbon emissions.

\section{A R T I C L E I N F O}

\section{Article history:}

Received 23 July 2014

Received in revised form

26 January 2015

Accepted 29 January 2015

Available online 29 January 2015

\section{Keywords:}

Ozone crop damage

Land use change

Emission scenarios

Air pollution control

Climate change mitigation

\begin{abstract}
A B S T R A C T
Exposure to surface ozone has detrimental impacts on vegetation and crop yields. In this study, we estimate ozone impacts on crop production and subsequent impacts on land use in the 2005-2050 period using results of the TM5 atmospheric chemistry and IMAGE integrated assessment model. For the crops represented in IMAGE, we compute relative yield losses based on published exposure-response functions. We examine scenarios with either constant or declining emission factors in a weak climate policy future (radiative forcing target of $6.0 \mathrm{~W} / \mathrm{m}^{2}$ at the end of the century), as well as co-benefits of stringent climate policy (targeted at $2.6 \mathrm{~W} / \mathrm{m}^{2}$ ). Without a large decrease in air pollutant emissions, higher ozone concentrations could lead to an increase in crop damage of up to $20 \%$ locally in 2050 compared to the situation in which the changes in ozone are not accounted for. This may lead to a $2.5 \%$ global increase in crop area, and a regional increase of $8.9 \%$ in Asia. Implementation of air pollution policies could limit crop yield losses due to ozone to maximally 10\% in 2050 in the most affected regions. Similar effects can be obtained as a result of co-benefits from climate policy (reducing ozone precursor emissions). We also evaluated the impact of the corresponding land-use changes on the carbon cycle. Under the worst-case scenario analysed in this study, future ozone increases are estimated to increase the cumulative net $\mathrm{CO}_{2}$ emissions between 2005 and 2050 by about $3.7 \mathrm{Pg} \mathrm{C}$, which corresponds to about $10 \%$ of baseline land use emissions over the same period.
\end{abstract}

(c) 2015 Elsevier Ltd. All rights reserved.

\section{Introduction}

Anthropogenic emissions of ozone precursors have increased surface ozone concentrations in many areas of the world (Royal Society, 2008). It has been demonstrated in field experiments conducted mostly in Europe and North America that exposure to

\footnotetext{
* Corresponding author. Postal address: P.O. Box 201, 3730 AE, De Bilt, The Netherlands.

E-mail address: chuwah@knmi.nl (C. Chuwah).
}

elevated ozone concentrations has detrimental effects on plants (e.g., Heck et al., 1983; Fuhrer et al., 1997; Pleijel et al., 2002; Karlsson et al., 2007; González-Fernández et al., 2008; De Bock et al., 2011). This ozone impact on plants has different implications: Firstly, it affects the productivity of crops and thus the global production of food. Secondly, it also negatively impacts natural vegetation. This may reduce biodiversity and contribute to global warming by reducing the $\mathrm{CO}_{2}$ uptake by plants (Sitch et al., 2007). Finally, ozone impacts on crops may also necessitate the need for additional agricultural cropland to meet food demand thus resulting in land use changes. 
Future changes in surface ozone are expected to vary regionally depending on the evolution of ozone precursors emissions. It is expected that the implementation of stringent air pollution policies will lead to a reduction in episodic peak ozone concentrations in Europe and North America (Ellingsen et al., 2008; Royal Society, 2008). At the same time, surface ozone concentrations are projected to increase in regions with rapidly growing economies in South and East Asia, at least in the near term. Young et al. (2013) presented multi-model projections of surface ozone concentrations based on the representative concentration pathways (RCPs). Chuwah et al. (2013) recently presented projections based on an extended set of RCP-like scenarios and showed that both air pollution and climate policy could significantly affect ozone precursor emissions and consequently ozone concentrations in the coming decades.

There have been a number of studies on present-day ozone impacts on crop yields, such as the global studies of Van Dingenen et al. (2009) and Avnery et al. (2011a) and the regional study for the United States by Yue and Unger (2014). In addition, scenario studies have investigated the possible impacts of future ozone levels on crop yields, such as the global studies by Avnery et al. (2011b; 2013) and the regional study for Asia by Wang and Mauzerall (2004), both based on the IPCC SRES scenarios (Nakićenović et al., 2000), the global study by Van Dingenen et al. (2009) based on emission scenarios from the International Institute for Applied Systems Analysis (IIASA), and the global study of Tai et al. (2014) based on the Representative Concentration Pathways (RCPs). Other studies have looked at the impacts of future changes in land use on ozone precursor emissions and ozone concentrations (Lathière et al., 2006; Ganzeveld et al., 2010; Wu et al., 2012). However, no attention has been given to the impacts of changes in surface ozone on land use via crop yield losses. In this study, we use a wider set of scenarios with respect to air pollution (Chuwah et al., 2013) developed using the Integrated Model to Assess the Global Environment (IMAGE, Bouwman et al., 2006) to assess the possible impacts of ozone concentration changes on future crop yields and consequently land use under different climate and air pollution policy regimes.

To do so, we make use of established exposure-response functions (ERFs) based on field experiments. The relative yield loss (RYL) factors for different crop types have been calculated from hourly ozone fields simulated with the atmospheric chemistry and transport model TM5 (Huijnen et al., 2010; Van Noije et al., 2014). The resulting crop production losses and the subsequent impact on land use were calculated by feeding back the results to the IMAGE model. This modelling setup allows us to assess the potential of different scenarios in reducing crop losses and subsequent impacts on land use for the first half of the century.

The paper is structured as follows: Section 2 describes the methodology. In Section 3 we present results on the simulated ozone indicators. Results on ozone impacts on crop production and land use, and the associated net $\mathrm{CO}_{2}$ emissions for the different scenarios are presented in Section 4. A discussion and conclusions of our results are given in Section 5.

\section{Methodology}

\subsection{Models and emission scenarios}

The ozone concentrations used in this study were calculated by Chuwah et al. (2013) using TM5, driven by present-day meteorological fields. This is justified by the fact that in most regions the impacts of climate change on ground-level ozone concentrations are expected to be much smaller than the impacts of future changes in ozone precursor emissions (see e.g. Fiore et al., 2012).
The three emission and land-use scenarios considered in this study have been developed using the IMAGE model, as described by Chuwah et al. (2013). We consider two scenarios that are similar to the RCP6.0 and RCP2.6, which lead to a radiative forcing of 6.0 and $2.6 \mathrm{~W} \mathrm{~m}^{-2}$ in 2100 respectively (Van Vuuren et al., 2011). The scenarios, called IM6.0 and IM2.6, differ in terms of energy use and land use as a consequence of the assumed climate policy. The IM6.0 is a scenario with very mild climate policy, while the IM2.6 scenario resembles the most ambitious climate policy scenarios in the literature. To assess the importance of air pollution policy we designed variants of these two climate scenarios with different trends in emission factors for ozone precursor gases and other short-lived air pollutants (Chuwah et al., 2013). The low air pollution scenarios assume that emission factors will decline following the implementation of currently formulated air pollution legislation up to 2030, followed by a further decline assuming that increasing levels of welfare lead to a higher valuation of air quality (similar to the Kuznets hypothesis). This is similar to the original RCPs, used in climate research (see Van Vuuren et al., 2011). In the high-pollution variants of these scenarios, current and planned legislation is assumed to be implemented until 2010, after which emission factors are taken to be constant. In this study, the following three scenarios are considered:

1) IM6.0-high (RCP6.0 type scenario, i.e. weak climate policy with high air pollutant emissions)

2) IM6.0-low (RCP6.0 type scenario, i.e. weak climate policy with low air pollutant emissions)

3) IM2.6-low (RCP2.6 type scenario, i.e. stringent climate policy with low air pollutant emissions).

A detailed description of the models and key assumptions about the emissions scenarios can be found in the Supplementary

Table 1

Overview of crop types in IMAGE, the different ozone indicators used to estimate ozone impacts and the exposure-response functions (ERFs) used to evaluate the relative yield loss (RYL). The mean of the RYL based on AOT40 and M7or M12 has been taken in the cases of rice and maize. Note that maize is both a food and energy crop in IMAGE.

\begin{tabular}{|c|c|c|c|c|}
\hline $\begin{array}{l}\text { IMAGE crop } \\
\text { types }\end{array}$ & $\begin{array}{l}\text { Crop types } \\
\text { used for } \\
\text { ERFs }\end{array}$ & $\begin{array}{l}\text { Ozone } \\
\text { indicator }\end{array}$ & $\begin{array}{l}\text { ERFs used for RYL } \\
\text { calculation }\end{array}$ & References \\
\hline Rice & Rice & $\begin{array}{l}\text { AOT40 } \\
\text { M7 }\end{array}$ & $\begin{array}{l}0.00415^{*} \text { AOT40 } \\
\left.\text { Exp[-(M7/137 })^{2.34}\right] / \\
\exp \left[-(25 / 137)^{2.34}\right]\end{array}$ & $\begin{array}{l}\text { Mills et al. (2007) } \\
\text { Wang and } \\
\text { Mauzerall (2004) }\end{array}$ \\
\hline Maize & Maize & $\begin{array}{l}\text { AOT40 } \\
\text { M12 }\end{array}$ & $\begin{array}{l}0.00356^{*} \text { АОТ } 40 \\
\text { Exp[-(M12/ } \\
\left.124)^{2.83}\right] / \exp [-(20 / \\
\left.124)^{2.83}\right]\end{array}$ & $\begin{array}{l}\text { Mills et al. (2007) } \\
\text { Wang and } \\
\text { Mauzerall (2004) }\end{array}$ \\
\hline $\begin{array}{c}\text { Temperate } \\
\text { cereals }\end{array}$ & Barley & AOT40 & $0.00061^{*}$ AOT40 & Mills et al. (2007) \\
\hline $\begin{array}{l}\text { Tropical } \\
\text { cereals }\end{array}$ & $\begin{array}{l}\text { Barley/ } \\
\text { wheat }\end{array}$ & AOT40 & $0.00061^{*}$ AOT40 & Mills et al. (2007) \\
\hline Pulses & Pulses & AOT40 & $0.0172 *$ АOT40 & Mills et al. (2007) \\
\hline Oil crop & Soybean & AOT40 & $0.0113^{*}$ AOT 40 & Mills et al. (2007) \\
\hline Grass & $\begin{array}{l}\text { Ryegrass/ } \\
\text { clover } \\
\text { mixture }\end{array}$ & AOT40 & $0.00003 *$ AOT40 & $\begin{array}{l}\text { González- } \\
\text { Fernández et al. } \\
(2008)\end{array}$ \\
\hline $\begin{array}{c}\text { Root and } \\
\text { Tuber }\end{array}$ & Potato & AOT40 & $0.0058^{*}$ АОТ 40 & Mills et al. (2007) \\
\hline Sugar cane & Cotton & AOT40 & $0.0150^{*}$ АОТ 40 & $\begin{array}{l}\text { Mills et al. (2007); } \\
\text { Grantz et al. (2009) }\end{array}$ \\
\hline $\begin{array}{l}\text { Woody bio- } \\
\text { fuel crops }\end{array}$ & $\begin{array}{l}\text { Broadleaves } \\
\text { and conifers }\end{array}$ & AOT40f & $0.00162 *$ AOT $40 \mathrm{f}$ & $\begin{array}{l}\text { Karlsson et al. } \\
\text { (2007) }\end{array}$ \\
\hline $\begin{array}{l}\text { Non-woody } \\
\text { bio-fuel } \\
\text { crops }\end{array}$ & Maize & AOT40 & $0.00356 *$ AOT40 & $\begin{array}{l}\text { Van Dingenen et al. } \\
\text { (2009) }\end{array}$ \\
\hline
\end{tabular}


material and in Chuwah et al. (2013) (including a detailed comparison with the original RCP emissions). Global totals for some key ozone precursors are presented in Fig. S1.

\subsection{Calculation of ozone indicators and relative yield loss factors}

To calculate crop yield losses due to exposure to ozone, we made use of ERFs for different crop types derived from large field experiments such as the National Crop Loss Assessment Network (NCLAN) in the United States and the European Open-Top Chamber Programme (see Table 1). In this study, the ozone indicators AOT40 (Mills et al., 2007), AOT40f (Karlsson et al., 2007), M7 and M12 (Wang and Mauzerall, 2004) were used (see Table 2). AOT40 (ppmv $\cdot \mathrm{h}$ ) is defined as the cumulative hourly ozone volume mixing ratio above a threshold of 40 ppbv during 12-h daylight (8:00-19:59) over the course of the growing season (normalized to 3 months). The definition of AOT40f (ppmv $\cdot h$ ), used in the case of forests, is similar to AOT40 except that it is normalized to 6 months. M7 and M12 (ppbv) are defined as the 7-h (09:00-15:59) and 12h (08:00-19:59) daytime mean ozone mixing ratio, respectively, during the growing season.

Many of the ERFs based on AOT40 are taken from the synthesis paper by Mills et al. (2007). Following van Dingenen et al. (2009), we have scaled the AOT40 and AOT40f based ERFs for the different crop types such that they equal unity at $\mathrm{AOT} 40(\mathrm{f})=0$ (see Table 1 ). The indices M7 and M12 are both considered in this study and other studies simply because the ERFs for rice are expressed as a function of M7 and those for maize as a function of M12. For rice and maize we follow the approach of van Dingenen et al. (2009) and take the average between the ERFs based on M7 and M12, respectively, and that based on AOT40.

For other crop types that are modelled in IMAGE but not covered by Mills et al. (2007), we applied the ERFs from published literature. In the case of grass, though a lot of studies have looked at the effect of ozone on grass (Fuhrer, 2009; González-Fernández et al., 2008), developing ERFs can be very complex because of varying responses of different species (Fuhrer, 2009). In this study, the ERF of rye grass/clover mixtures from González-Fernández et al. (2008) is used, which show relatively small sensitivity to ozone. For woody bio-fuel plants, we use the ERF for conifer and broadleaves from Karlsson et al. (2007).

For some of the crop types modelled in IMAGE, no suitable ERFs were found in the literature. For these crop types, we applied the ERFs of crops from Mills et al. (2007) with broadly similar plant functional type classification. For instance, in the case of temperate cereals (where no suitable ERFs were found), we applied the ERF of barley (Mills et al., 2007). With regard to tropical cereals, which show moderate sensitivity to ozone, we used the average of the ERFs of wheat and barley. For root and tuber, we use the ERF of potato. For the non-woody bio-fuel crops, we use the ERF of maize, which is one of the crops used in producing bio-fuel. With respect

Table 2

Definition of the different ozone indicators used in the computation of crop relative yield. Here $\left[\mathrm{O}_{3}\right]$ represents hourly ozone concentration, $\mathrm{i}$ is the hour index, and $n$ depicts the number of hours in the growing season.

\begin{tabular}{ll}
\hline Definition & References \\
\hline AOT40 $(p p m h)=\sum_{i=1}^{n}\left(\left[O_{3}\right]_{i}-40\right),\left[O_{3}\right] \geq 40 p p b v$ & Mills et al., 2007 \\
08:00-19:59 & \\
AOT40f $(p p m h)=\sum_{i=1}^{n}\left(\left[O_{3}\right]_{i}-40\right),\left[O_{3}\right] \geq 40 p p b v$ & Karlsson et al., 2007 \\
08:00-19:59 & \\
$M 12(p p b v)=\frac{1}{n} \sum_{i=1}^{n}\left[O_{3}\right]_{i}$ & Wang and Mauzerall, 2004 \\
08:00-19:59 & \\
$M 7(p p b v)=\frac{1}{n} \sum_{i=1}^{n}\left[O_{3}\right]_{i}$ & Wang and Mauzerall, 2004 \\
09:00-15:59 & \\
\hline
\end{tabular}

to sugar cane, no suitable ERF was found. However, Grantz and Vu (2009) reported that sugar cane exhibits the same sensitivity to ozone as cotton at moderate levels of exposure and as tomato at high levels of exposure. Therefore, we used the ERF of cotton for sugar cane.

The same ERFs derived from field experiments in Europe and North America are applied globally as very little information was available on ERFs in the tropics. However, a comparison of crop sensitivities from a small scale study in Asia and North America revealed that Asian crops are more sensitive than North American crops (Aunan et al., 2000; Emberson et al., 2009). Thus our estimates of ozone effects on Asian crops are likely conservative.

The ozone indicators are calculated using the local growing season as determined in IMAGE. Thus, we estimated the ozone indicators by averaging (M7 and M12) or summing (AOT40 and AOT40f) hourly ozone fields between the start and end of the growing season. Following their definitions, AOT40 and AOT40f were then normalized to 3 months (Van Dingenen et al., 2009) and 6 months (Karenlampi and Skärby, 1996), respectively. The resulting ozone indicators were used to calculate the RYL factors for the various crops used in IMAGE (see Table 1). It is important to note that the growing season used in the calculation of the ozone indicators in this study is fixed to 2005 conditions, which implies that only the impacts of changes in ozone precursor emissions on the ozone indicators and the resulting RYL factors are explored. The RYL factors are calculated based on simulated ozone mixing ratios for the years 2005, 2020 and 2050. For the intermediate years, the RYL factors are obtained by linear interpolation in time.

\subsection{Calculation of crop production loss}

In IMAGE, the simulated crop productions and crop areas are calibrated to FAO crop production and resource data from 1970 to present-day to ensure that they are consistent with aggregated agricultural statistics at national and global levels by adjusting the so-called management factor representing the human influence on crop yields (details on this can be found in Bouwman et al., 2006). In fact, in this way IMAGE implicitly accounts for ozone impacts for the present-day as these are implicitly included in the FAO production statistics. To correct for this effect, we apply the following formula to calculate the ozone impact on the crop production per grid cell in IMAGE:

$C P_{i}($ year $)=\frac{1-R Y L_{i}(\text { year })}{1-R Y L_{i}(2005)} \times C P_{i}^{o}($ year $)$.

Here $C P_{i}$ is the potential crop yield of crop type $i$ in a particular year that explicitly accounts for ozone impacts, and $C P_{i}^{o}$ is the corresponding yield derived from the original IMAGE model, i.e. without explicit ozone impacts. In the paper, we only use this equation to estimate the relative future losses compared today. Crop production loss $\left(C P L_{i}\right)$ per grid cell for the different food crops represented in IMAGE are equal to:

$C P L_{i}($ year $)=\frac{R Y L_{i}(\text { year })}{1-R Y L_{i}(\text { year })} \times C P_{i}($ year $)$.

\subsection{Simulations for estimating the impacts on land use and the carbon cycle}

At regional and global scales our IMAGE simulations meet the same required crop production irrespective of whether or not the impacts of changes in surface ozone are accounted for. This means that the crop yield loss or gain due to ozone changes is 
compensated through expansion or abandonment of agricultural land. To estimate this indirect effect of ozone on future land use and the carbon cycle, we have performed five simulations using our three IMAGE scenarios: two control runs with IM2.6-low and IM6.0-low, indicated by IM6.0-orig and IM2.6-orig, in which the impacts of future ozone changes on crops are not explicitly included, and the three runs for IM6.0-high, IM6.0-low and IM2.6low wherein these impact are explicitly accounted for (Table 3). By comparing simulations with and without impacts of future ozone changes on crops for the same climate forcing scenario, we can separate the ozone impacts on crops from other drivers, such as climate change. Since the regional and global crop production is determined by the food demand, in calculating the crop production loss due to ozone effects using the equation given above, we assume that the crop production is the same as in IM6.0-orig and IM2.6-orig, respectively, thereby neglecting small differences in crop production at the local scale.

\section{Results on ozone indicators}

\subsection{Evaluation of ozone indicators for present day}

Simulated surface and tropospheric ozone concentrations from TM5 have been extensively evaluated against observations (Huijnen et al., 2010; Chuwah et al., 2013; Van Noije et al., 2014). Here, we evaluate the model with respect to its ability in capturing the ozone indicators introduced in the previous section as well as the corresponding monthly values for the year 2005. To this end, we have selected rural background stations providing hourly surface ozone measurements. We considered stations from the European Monitoring and Evaluation Programme (EMEP), the European air quality database (AIRBASE), the Clean Air Status and Trends Network (CASTNET) and the World Data Centre for Greenhouse Gases (WDCGG). We selected only stations which provided data at least $90 \%$ of the time during the growing season, as determined from the IMAGE model for the selected year. In Europe and the United States (US) there is sufficient data coverage to enable a regional comparison between the modelled and observations based ozone indicator. The locations of the remaining stations used in our evaluation and the demarcation of the regions used in our regional analysis are shown in Fig. 1. The simulated ozone data are linearly interpolated to the station locations. Additionally, we account for station heights by interpolating to the station pressure based on a standard atmosphere. Regional means are calculated by taking the mean over all stations within a given region.

The monthly 12-h averaged ozone mixing ratio (M12) from the model and the selected background stations for different regions are presented in Fig. 2. A similar comparison for AOT40 is shown in the Supplementary material (Fig. S2). The error bars show one standard deviation of the values obtained for the individual stations. In addition, ratios between the regionally averaged measured and simulated ozone indicators averaged (M7 and M12) or summed (AOT40 and AOT40f) over the full growing season are listed in Table 4. This comparison shows that the amplitude of the monthly M12 metric is generally well captured by TM5. In general, the

Table 3

Overview of the IMAGE simulations performed for this study.

\begin{tabular}{ll}
\hline Simulations & Changing ozone damage on crops \\
\hline IM6.0-orig & No \\
IM2.6-orig & No \\
IM6.0-high & Yes \\
IM6.0-low & Yes \\
IM2.6-low & Yes \\
\hline
\end{tabular}

model shows a positive offset in the summer in all considered regions in Europe and the US. The biases in Europe can be as high as about $15 \mathrm{ppbv}$ in the summer months. The largest biases are found in the US. In summer they reach 25 ppbv in the northeastern US, which is highly significant compared to the variability among the stations included for this region. For Japan, TM5 systematically over-predicts the 12-h daytime mean surface ozone by up to 30 ppbv at the two selected stations in the spring and summer months. Averaged over the whole growing season the model reproduces M12 to within 13\% in Europe and 21\% in the US.

AOT40 and AOT40f are more sensitive to model biases because of the 40 ppbv threshold. While TM5 captures the observed AOT40 reasonably well in Europe, the results in the US are less robust as our modelled AOT40 is approximately twice as high as the observed values (Table 4). The reasons for the observed mismatches especially in the US can have various causes related to representation of chemical and physical processes in the model. Biases in the applied emissions of ozone precursors and the relatively coarse horizontal resolution of the model (Wild and Prather, 2006) likely also contribute substantially to the observed discrepancies.

The observed biases between measured and observed ozone especially for AOT40 is of great importance as calculated RYL might be significantly overestimated in the US. To reduce this error, we applied a correction to the model results for the different ozone indicators. This is achieved by scaling the simulated ozone indicators, obtained per grid cell for the whole growing season. The scale factor is obtained on a regional level as the ratio of the regional mean observed to modelled value for the corresponding ozone indicator. We are not able to perform a similar bias correction in Asia, Africa and South America because of the lack of representative networks of measurement stations of hourly surface ozone data for 2005. This implies that the estimated RYL calculated in these regions are sensitive to model biases. However, when considering the impacts of future changes in ozone concentrations, biases in present-day and future ozone concentrations partially cancel each other.

\subsection{Future projections of ozone indicators}

Fig. 3 shows the simulated M12 and AOT40 fields and changes in 2050 relative to 2005 under the IM2.6-low, IM6.0-low and IM6.0high scenarios. The data shown for Europe and the US are the model results after the application of the bias correction. Results for present-day seasonal mean ozone concentrations (M12) are typically around 40-60 ppbv in the northern hemisphere industrialized regions, with values reaching around 60 ppbv in parts of India and China. In most of the northern hemisphere mid-latitudes and central Africa, we find AOT40 values higher than the $3 \mathrm{ppmv} \cdot \mathrm{h}$ limit necessary to curtail ozone impact on crops (see Karenlampi and Skärby, 1996). Under the IM6.0-high scenario, we find a strong increase in surface ozone concentrations exceeding 20 ppbv for M12 and $15 \mathrm{ppmv} \cdot \mathrm{h}$ for AOT40. The increase is principally strong in the Indian subcontinent. However, we also see decreases in surface ozone concentrations mostly in the Congo and Amazon basins.

Comparison of simulated ozone concentrations under the different scenarios shows that future changes in surface ozone strongly depend on the assumed level of air pollution control and climate policy. For instance, the implementation of all current and planned legislation and additional air pollution abatement measures (IM6.0-low) decreases both M12 and AOT40, as seen most noticeably in the eastern United States, part of the Mediterranean, northwestern Europe and central Eurasia. If more stringent climate and air pollution measures are put in place (IM2.6-low), both indicators will be reduced over the entire globe - with reductions up to about $15 \mathrm{ppbv}$ and $15 \mathrm{ppmv} \cdot \mathrm{h}$, respectively, simulated in 


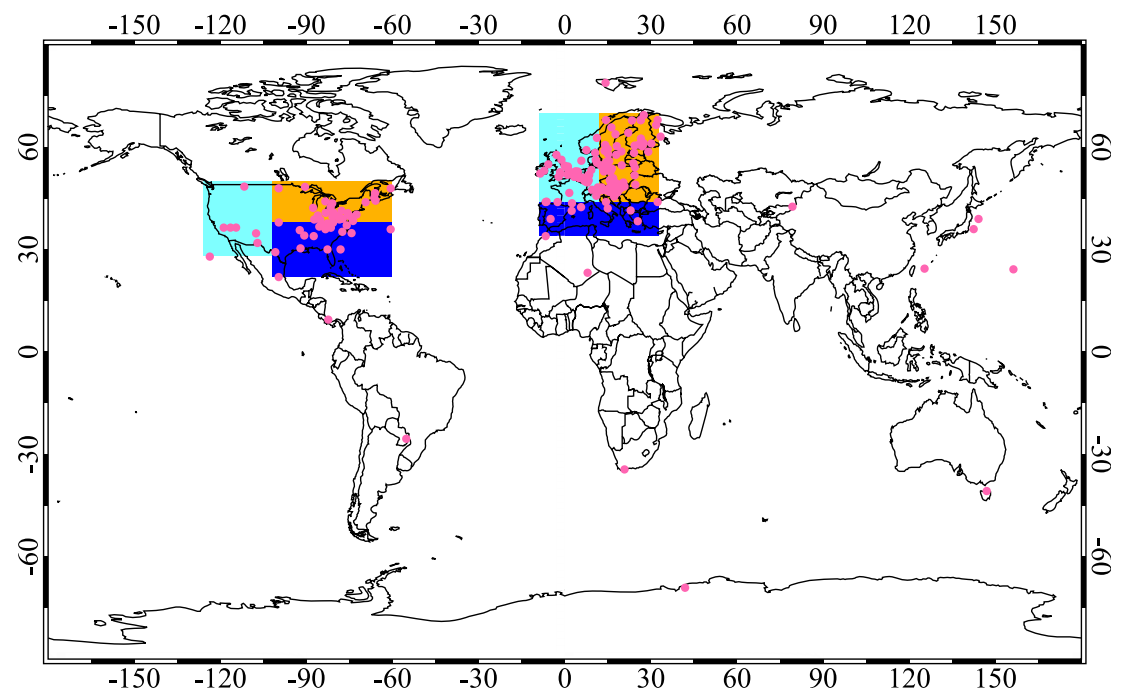

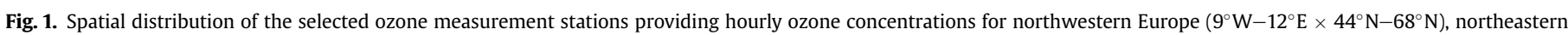

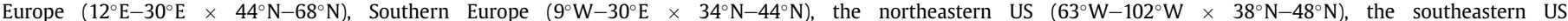
$\left(63^{\circ} \mathrm{W}-102^{\circ} \mathrm{W} \times 22^{\circ} \mathrm{N}-38^{\circ} \mathrm{N}\right)$ and the western US $\left(102^{\circ} \mathrm{W}-126^{\circ} \mathrm{W} \times 28^{\circ} \mathrm{N}-50^{\circ} \mathrm{N}\right)$.
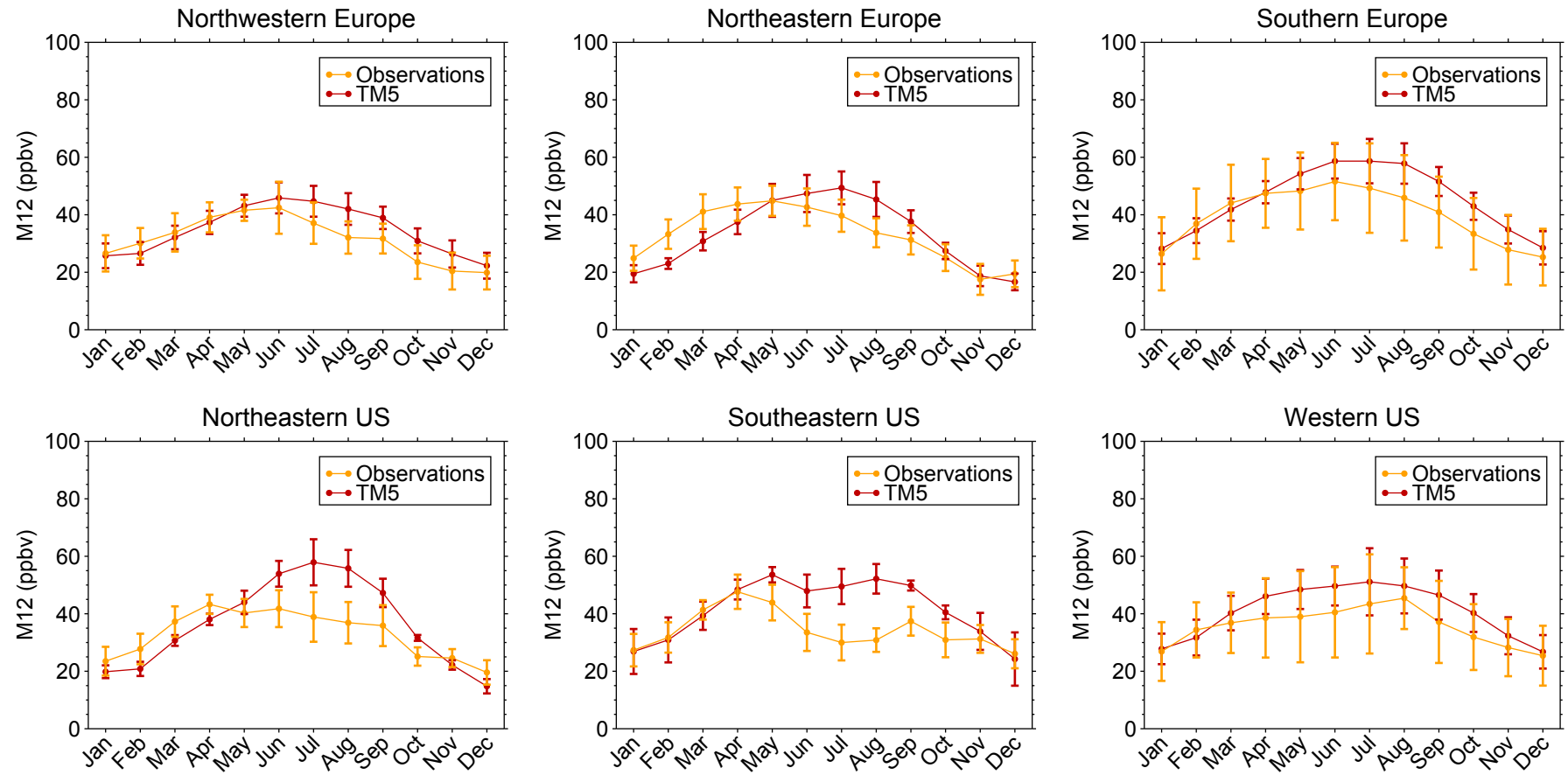

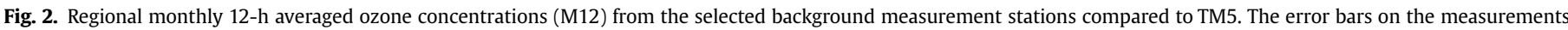
and simulation show one standard deviation of the monthly means for the different station locations in a given region.

northern mid-latitudes.

\section{Ozone impact on crops, land use and the carbon cycle}

\subsection{Ozone impacts for the present day}

Fig. 4 shows the results for the ozone induced relative yield loss for maize and rice, two important crop types in IMAGE. These two crops have already been assessed on a global scale by Van Dingenen et al. (2009) and Avnery et al. (2011a). This enables a comparison of our results to their findings. Based on present-day (2005) ozone levels, a RYL of up to about $10 \%$ is estimated for both crops especially in parts of the Middle East, India and China where high ozone concentrations are simulated during the growing season. Comparison of our RYL estimates for maize and rice with the results of Van Dingenen et al. (2009) for the present-day reveals similar global patterns with RYL factors also reaching values around $10 \%$ locally. In Europe and the US where our results are less affected by model biases, we estimate RYL factors of maximally about $4 \%$ for maize in both regions and for rice in the US which is lower than the maximum values of about 10\% computed by Van Dingenen et al. (2009) and 6\% found for maize by Avnery et al. (2011a). Part of this discrepancy is due to the fact that we have corrected for biases in the simulated ozone concentrations. Without this bias 
Table 4

Ratio of regional averages of the measured to simulated ozone indicators between the start and end of the growing period.

\begin{tabular}{llll}
\hline Regions & M7 & M12 & AOT40 \\
\hline Northwestern Europe & 0.89 & 0.87 & 0.89 \\
Northeastern Europe & 0.85 & 0.88 & 0.77 \\
Southern Europe & 0.91 & 0.90 & 0.93 \\
Northeastern US & 0.85 & 0.79 & 0.54 \\
Southeastern US & 0.88 & 0.84 & 0.60 \\
Western US & 0.87 & 0.83 & 0.51 \\
\hline
\end{tabular}

correction, we find maximal RYL of about $8 \%$ in parts of Europe and the US (Fig. S3). Differences are also caused by the fact that we used the growing season from IMAGE in our computation of the ozone indicators, while the crop calendar from the US Department of Agriculture was used in the studies by Van Dingenen et al. (2009) and Avnery et al. (2011a).

The estimated crop production loss varies regionally and between crop types as they portray different sensitivities to ozone (Fig. 5). The corresponding crop production from which CPL is computed is presented in the supplementary material (Fig. S4). For 2005, we estimate losses of up to 5 metric tons $/ \mathrm{km}^{2}$ for maize and rice in Asia which is akin to the present-day estimate of Van Dingenen et al. (2009). Similarly, we find small CPLs in the US for rice. However, for maize our computed CPL $\left(0.5\right.$ metric tons $\left./ \mathrm{km}^{2}\right)$ in the northeastern US is smaller than the 5 metric tons $/ \mathrm{km}^{2}$ estimated by Van Dingenen et al. (2009). Without the bias correction, estimated CPL for maize reaches 1 metric tons $/ \mathrm{km}^{2}$ in this region (Fig. S5). While these differences stem partly from the applied bias correction, they are also associated with the fact that the estimated maize production in Van Dingenen et al. (2009) for this region is higher than that simulated in IMAGE. Though there are spatial and temporal differences, the present-day ozone impact on maize production averaged over the US decreases by $48 \%$ when the bias correction was applied and by $27 \%$ in Europe. For rice, we find a decrease of about $40 \%$ in the US and $16 \%$ in Europe after the application of bias correction.

\subsection{Future impacts of ozone on crops}

The effect of future ozone-induced crop losses can also be seen in Figs. 4 and 5. Under the scenario with little air pollution control (IM6.0-high), we find for both crops high RYLs exceeding 20\% in 2050 in most parts of the Middle East, India and China. Avnery et al. (2011b) using the A2 scenario also estimated RYL for maize of up to $20 \%$ in these regions in 2030 for M12. The implementation of stringent air pollution policy results in a decrease in projected RYL for maize and rice compared to 2005 values especially in the US, southern Europe, the Middle East, India and China. Despite the stringent air pollution policy in place, we still find RYL exceeding 15\% mainly in some parts of India and China in 2050.

If air pollution policies are not tightened (IM6.0-high) in 2050, CPL might get up to 10 metric tons $/ \mathrm{km}^{2}$ especially in Asia. At the same time, crop production losses up to 2 metric tons $/ \mathrm{km}^{2}$ for maize are also noted in the US (up to 5 metric tons $/ \mathrm{km}^{2}$ without bias correction), Southern Europe and central Africa. In contrast, the implementation of air pollution mitigation measures leads to lower CPL under IM6.0-low compared to IM6.0-high, most noticeably in parts of the US and Southern Europe. Irrespective of the stringent policy in place, CPL in some parts of India and China still gets up to 10 metric tons $/ \mathrm{km}^{2}$

\subsection{Impact on land use}

Fig. 6 shows global and regional (see Bouwman et al., 2006 for regional definition) ozone impacts on land use through crop yield losses and the resulting expansion in agricultural areas under the three scenarios evaluated in this study and also two simulations without changes in ozone effects (IM2.6-orig and IM6.0-orig). In the latter simulations ozone impacts are only included implicitly based on FAO crop production data for the present day. The difference between the solid and dashed lines gives the impacts of future ozone changes on land use via crop yield loss. If air pollution measures are not enforced as assumed in IM6.0-high, crop yield losses due to ozone changes will lead to an increase in global crop area of approximately 1.3 million $\mathrm{km}^{2}$ (2.5\%) in 2050. Regionally, we find the highest increases of up to $8.9 \%$ in Asia, $2.7 \%$ in Western Europe and $1.1 \%$ in North America. Without bias correction, we estimate higher increases in regional crop area in North America (1.6\%) and Western Europe (3.2\%). Implementation of current and planned air pollution legislation till 2030 and additional abatement measures thereafter (IM6.0-low), leads to small impacts of crop yield losses on crop area globally and in most regions except in Asia, where increases in crop area of up to 3.6\% are estimated in 2050. This implies that additional measures to control the emissions of ozone precursors would be needed in order to further curb the impact of surface ozone on crop yield and land use.

\subsection{Impacts of climate policy on crop yields and land use}

The effect of climate policy on ozone-induced crop losses can be evaluated by comparing the IM6.0-low and IM2.6-low scenarios (Figs. 4-6). Interestingly, these Figures show that climate policy can has significant co-benefits by reducing the ozone impacts on crop yields. For instance, in India and China, which are the most affected regions, we find RYL reaching $10 \%$ for maize and $8 \%$ for rice under IM2.6-low compared to $15 \%$ or more for maize and rice under IM6.0-low. The co-benefits of climate policy can also be seen in the lower CPL especially in the US and Southern Europe. Even without bias correction, the CPL is still relatively low in these regions. Also in Asia, CPL decreases from a maximum of about 10 metric tons $/ \mathrm{km}^{2}$ to approximately 5 metric tons $/ \mathrm{km}^{2}$ following the implementation of climate policy.

It should be noted that while the climate mitigation scenario (IM2.6-low) requires less land in response to ozone damage, it needs more land use for bio-energy production that forms part of the mitigation portfolio. Overall, this leads to an increase of agricultural area of $4.8 \%$ globally. Regionally, significant increases in crop area are found most notably in Eurasia (14.2\%), North America (9.3\%), Asia (5.5\%) and Western Europe (3.9\%). In IMAGE, bio-energy crops are cultivated mostly on abandoned agricultural land and grassland mainly in OECD countries and the former Soviet Union in the first half of the century (see Van Vuuren et al., 2007). The indirect impact of ozone on land use (depicted by the difference between (IM2.6-low and IM2.6-org) is small because stringent climate and air pollution policies measures assumed under these scenarios lead to a reduction of the emission of ozone precursors and hence limit the severity of ozone damage on crops.

\subsection{Impact on the carbon cycle}

Table 5 gives the cumulative net $\mathrm{CO}_{2}$ emissions to the atmosphere from land use between 2005 and 2050. We estimate negative cumulative $\mathrm{CO}_{2}$ emissions for all our scenarios in North America and Western Europe as re-growth of vegetation on abandoned agricultural land leads to significant uptake of carbon. The indirect impact of ozone changes on $\mathrm{CO}_{2}$ emissions through 
IM2005

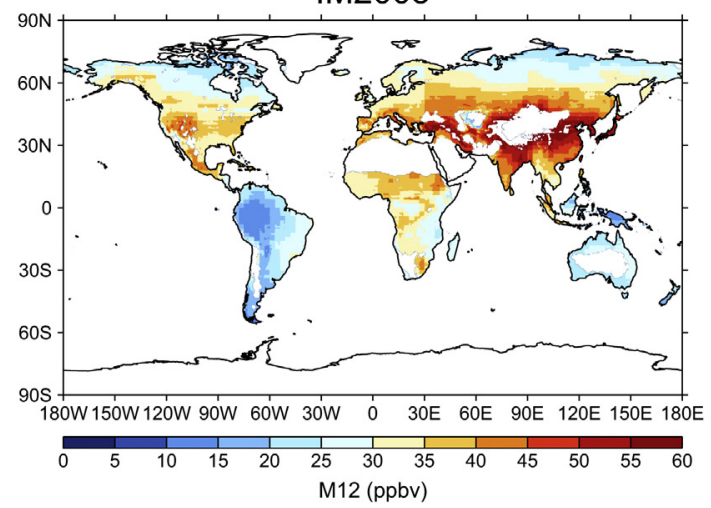

IM2.6-low 2050 - IM2005

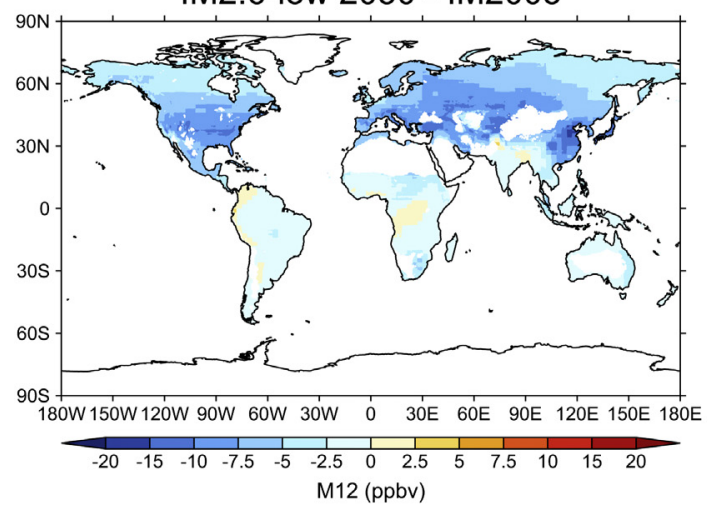

IM6.0-low 2050 - IM2005

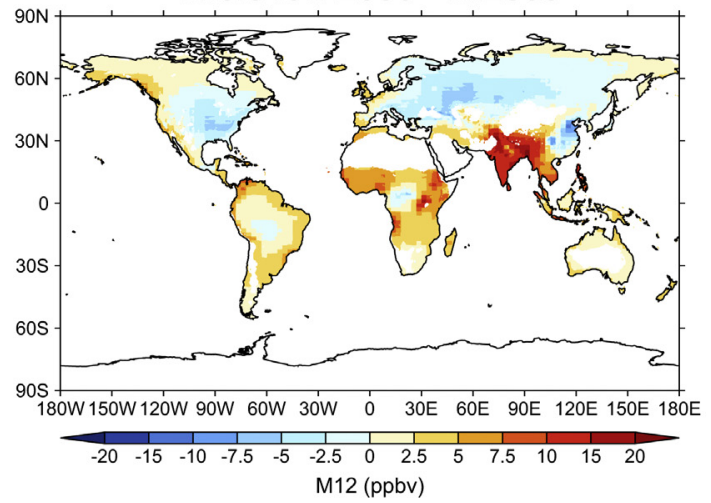

IM6.0-high 2050 - IM2005

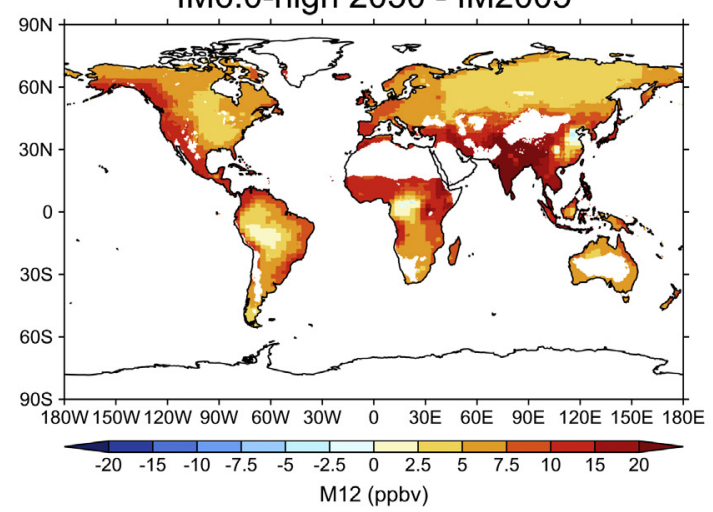

IM2005

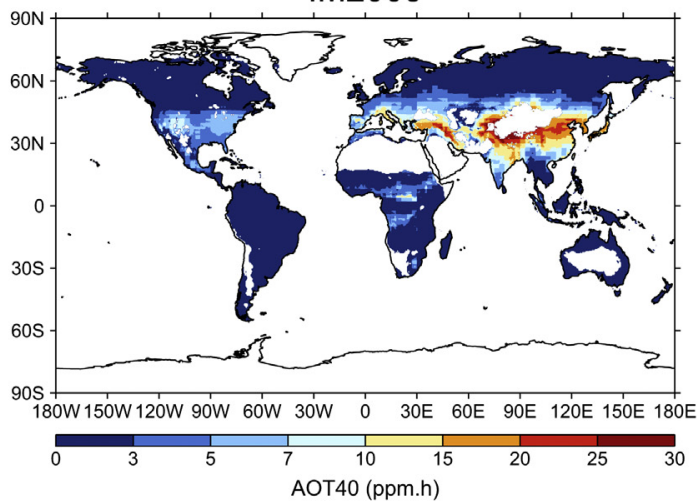

IM2.6-low 2050 - IM2005

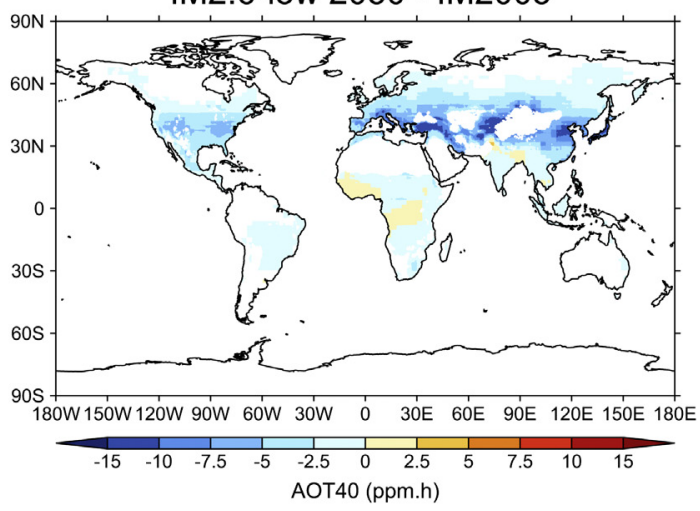

IM6.0-low 2050 - IM2005

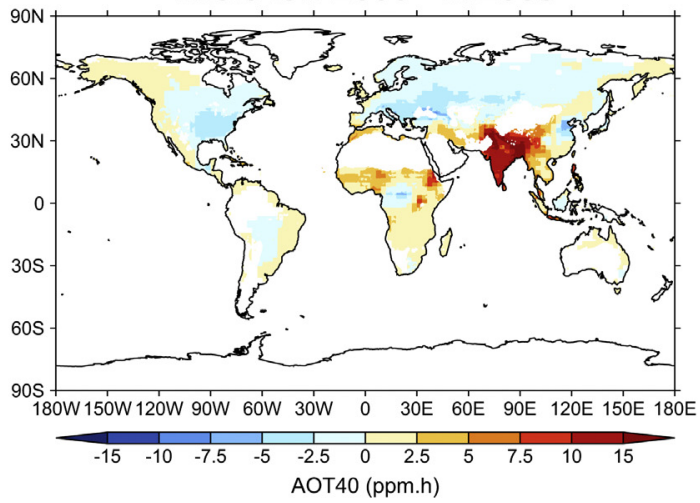

IM6.0-high 2050 - IM2005

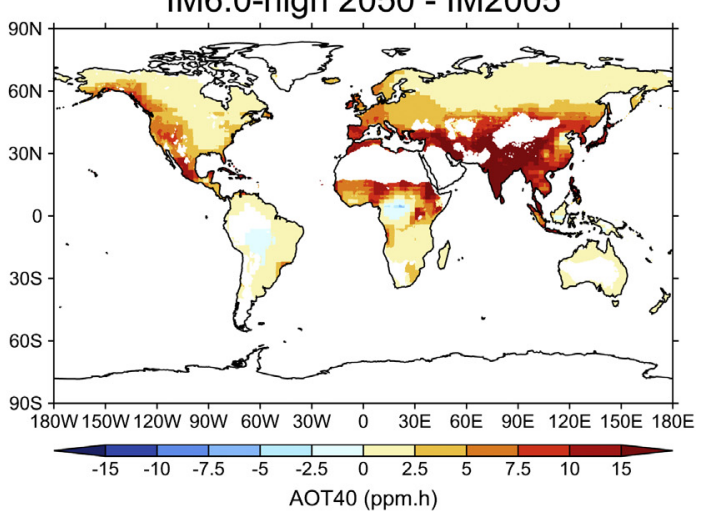

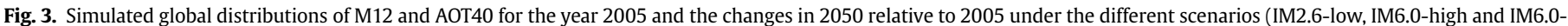
low) after mean bias correction in Europe and North America. 
Maize, RYL IM2005

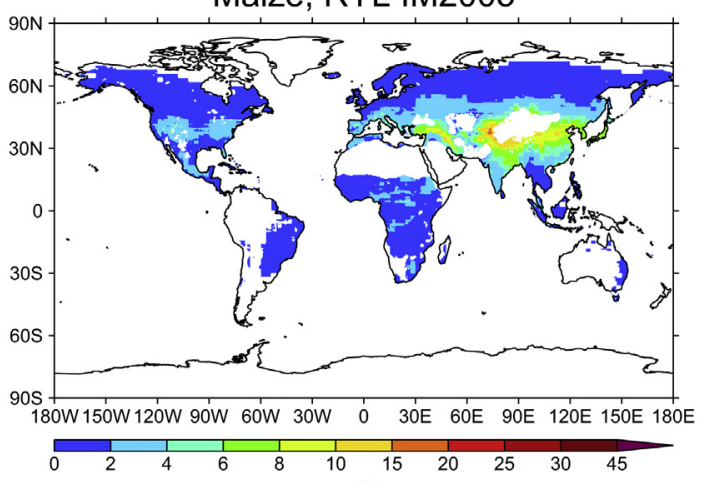

(\%)

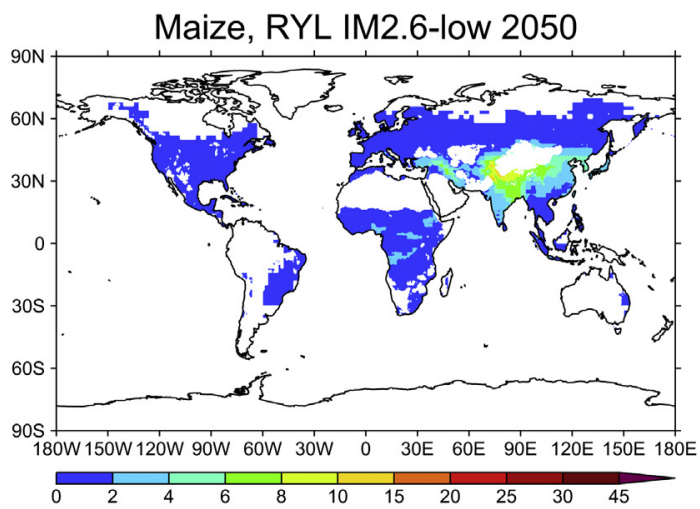

(\%)

Maize, RYL IM6.0-low 2050

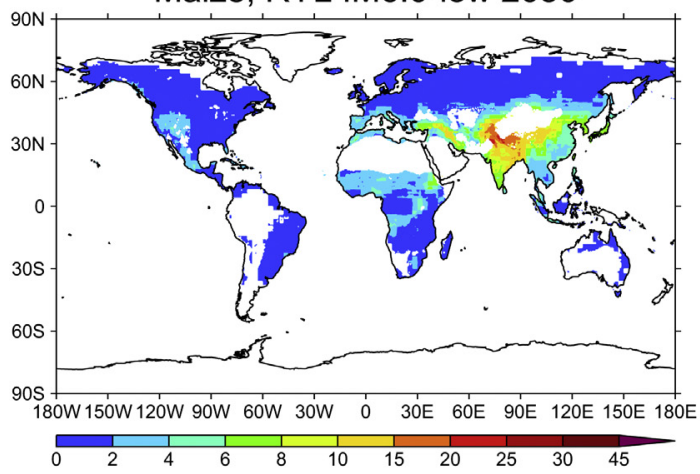

(\%)

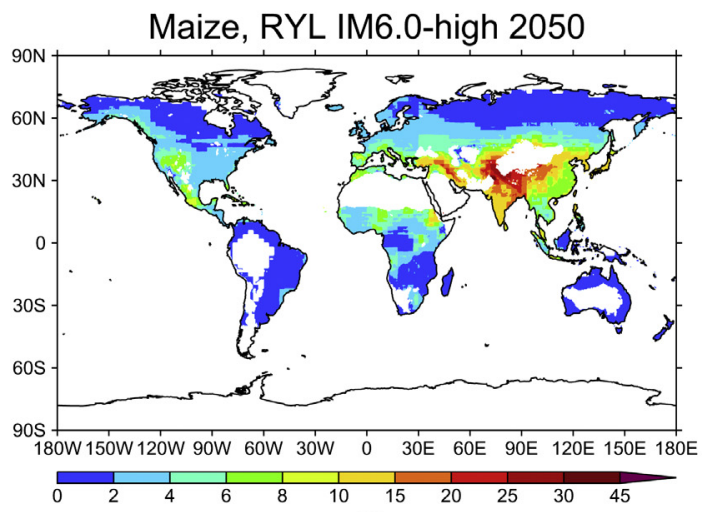

(\%)
Rice, RYL IM2005

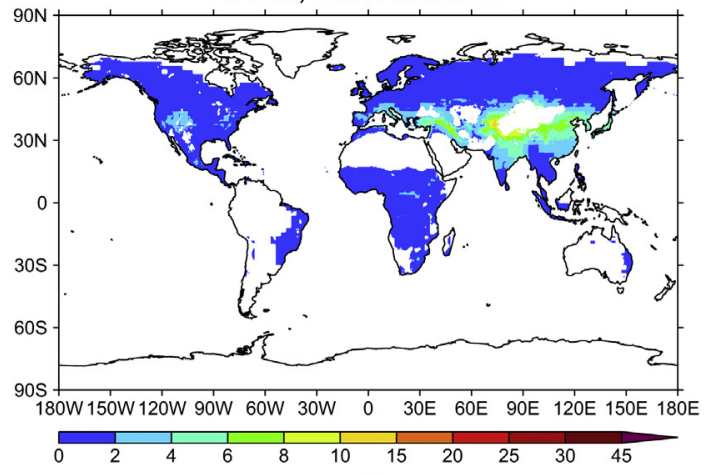

(\%)

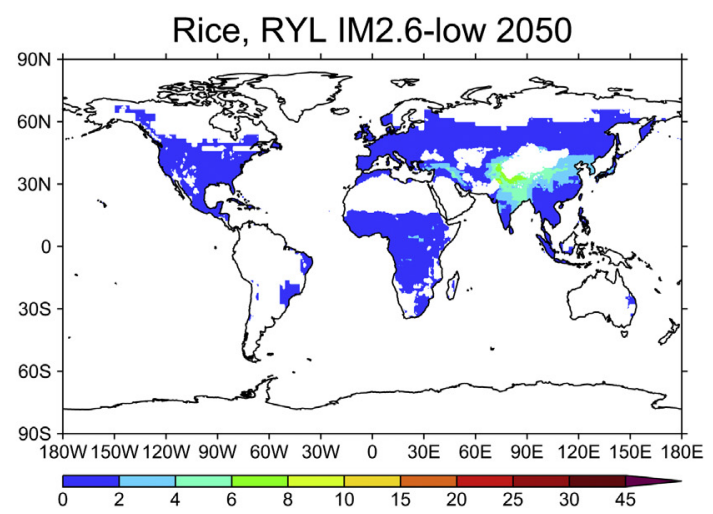

$(\%)$

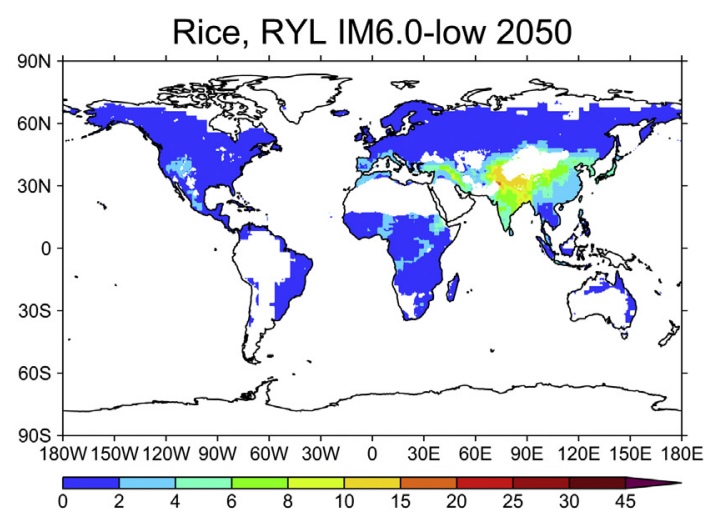

(\%)

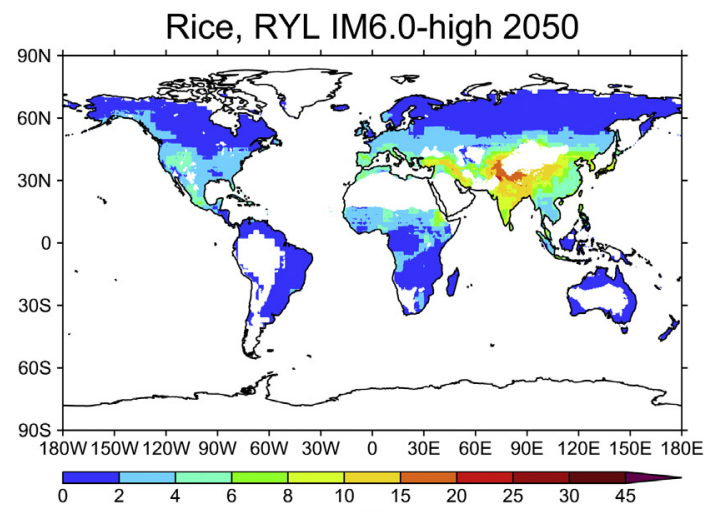

(\%)

Fig. 4. Estimated relative yield loss for maize and rice for the present day (2005) and three scenarios for 2050. 
Maize CPL 2005

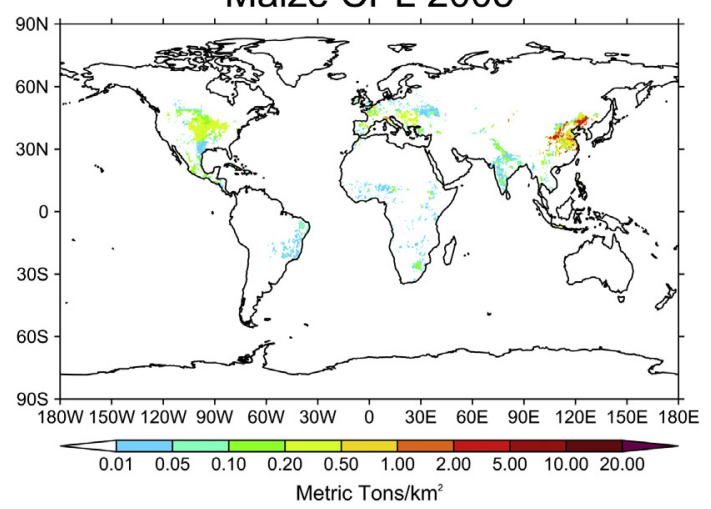

Maize CPL IM2.6-low 2050

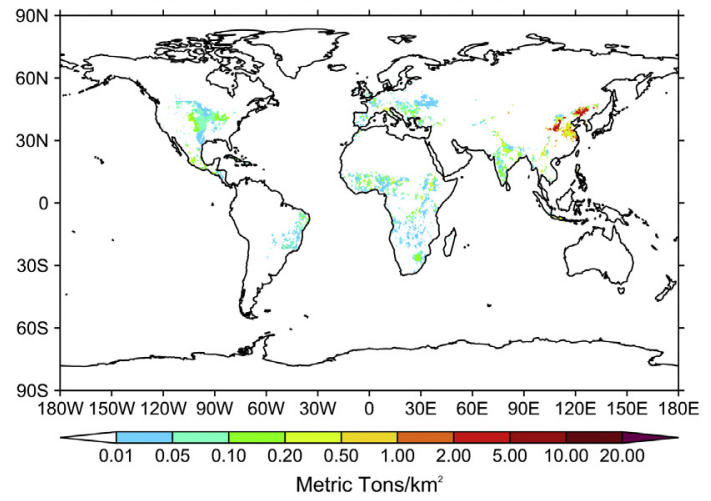

Maize CPL IM6.0-low 2050

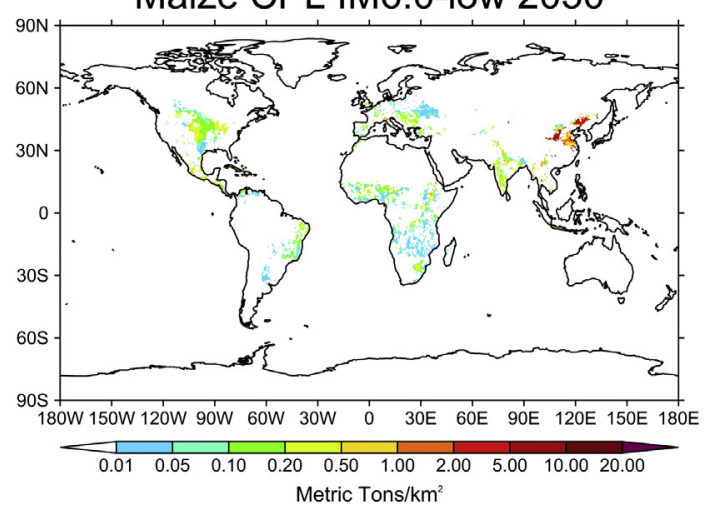

Maize CPL IM6.0-high 2050

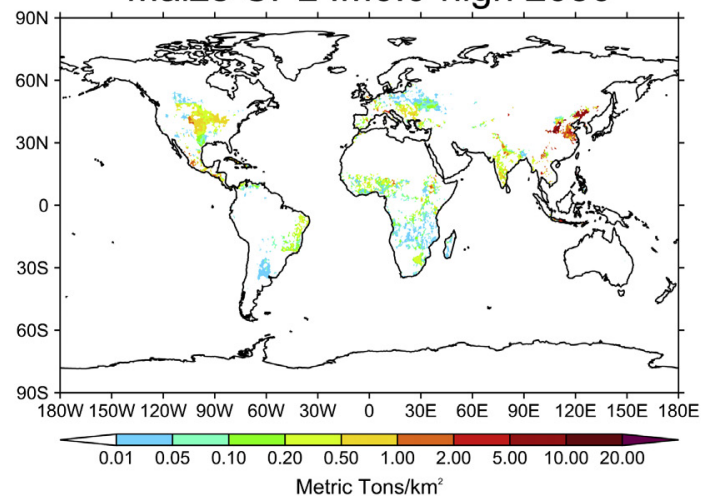

Rice CPL 2005

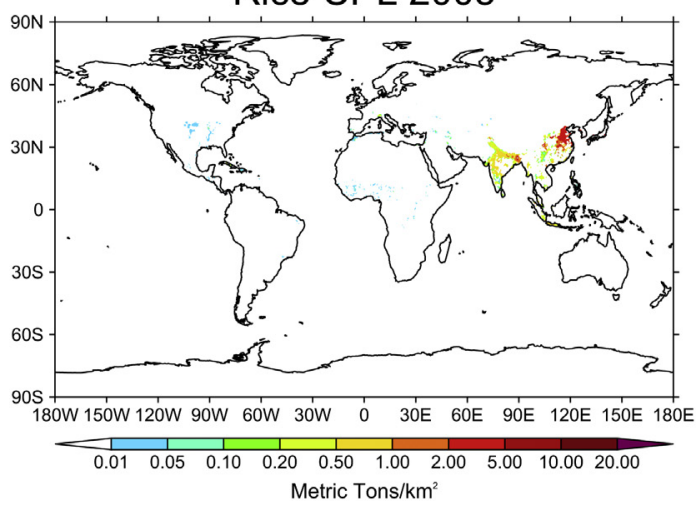

Rice CPL IM2.6-low 2050

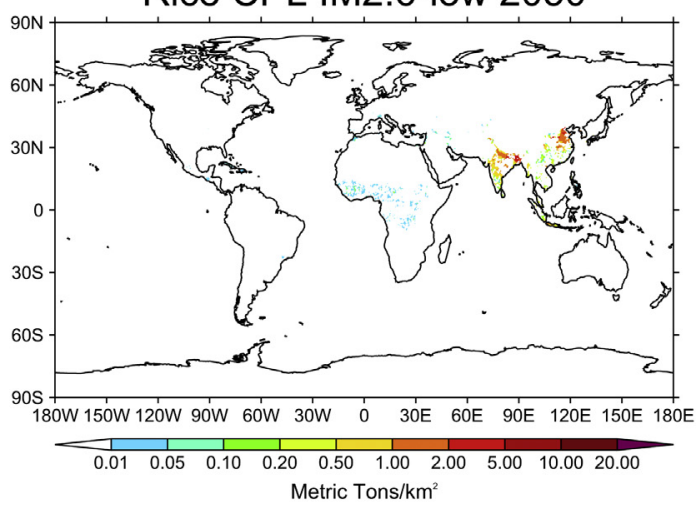

Rice CPL IM6.0-low 2050

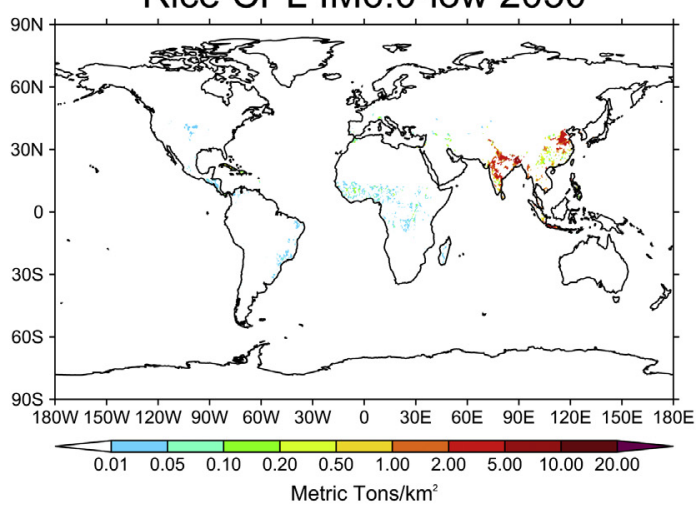

Rice CPL IM6.0-high 2050

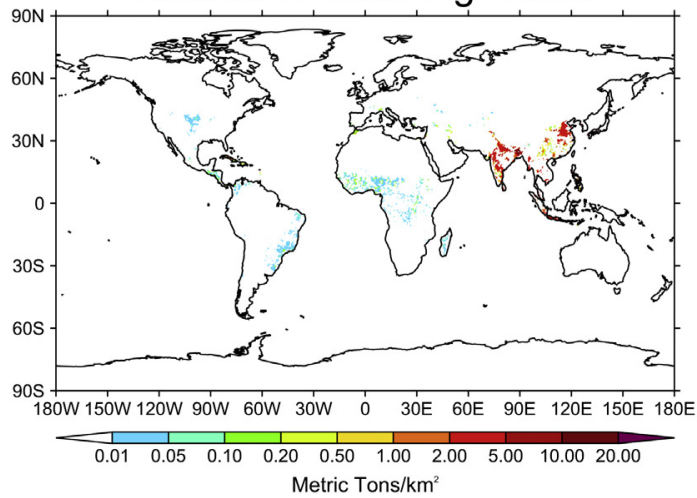

Fig. 5. Crop production loss (CPL) for 2005 and 2050, under IM2.6-low, IM6.0-low and IM6.0-high for maize and rice. 

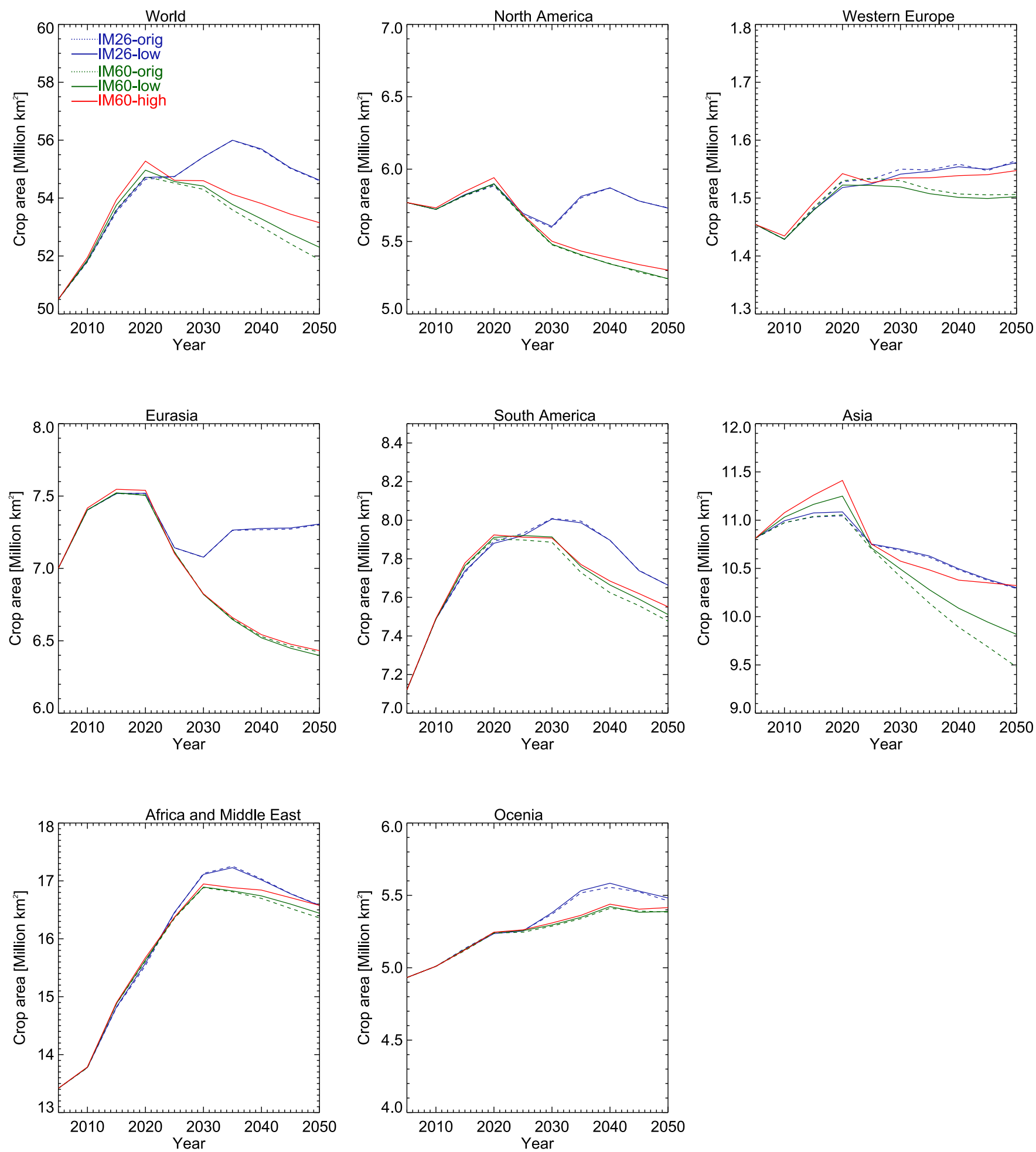

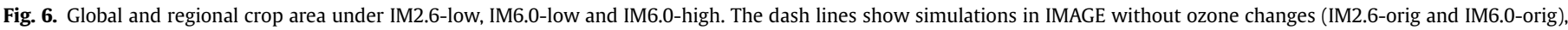
while the solid lines correspond to simulations that account for impacts of ozone changes.

changes in land use is rather small in most parts of the globe. On a global scale, we find the highest increase in the cumulative $\mathrm{CO}_{2}$ emissions due to impacts of ozone changes on crops under the IM6.0-high scenario, where we estimate an increase of about 3.7 Pg C (10.4\%) compared to the case without ozone changes. Compared to the anthropogenic $\mathrm{CO}_{2}$ emissions from fossil fuel combustion and cement production $(9.5 \pm 0.8 \mathrm{Pg} \mathrm{C}$ in 2011 ; Ciais et al., 2013) these are relatively small numbers. However, in Asia a significant increase of the cumulative $\mathrm{CO}_{2}$ emissions from land use can be noticed due the impacts of ozone increases under both the IM6.0-low (26.2\%) and IM6.0-high (52.4\%) scenarios. The impact of ozone changes on $\mathrm{CO}_{2}$ emissions is relative small in Eurasia, South America, Africa, the Middle East and Oceania. Hence, the $10 \%$ increase under IM6.0-high is dominated by the increased 
Table 5

Regional and global cumulative net $\mathrm{CO}_{2}$ emission $(\mathrm{Pg} \mathrm{C})$ to the atmosphere from land use between 2005 and 2050.

\begin{tabular}{lccccc}
\hline Regions & $\begin{array}{l}\text { IM2.6- } \\
\text { orig }\end{array}$ & $\begin{array}{l}\text { IM2.6- } \\
\text { low }\end{array}$ & $\begin{array}{l}\text { IM6.0- } \\
\text { orig }\end{array}$ & $\begin{array}{l}\text { IM6.0- } \\
\text { low }\end{array}$ & $\begin{array}{l}\text { IM6.0- } \\
\text { high }\end{array}$ \\
\hline North America & -0.57 & -0.43 & -1.19 & -1.02 & -0.91 \\
Western Europe & -1.13 & -1.11 & -1.13 & -1.11 & -1.07 \\
Eurasia & 3.37 & 3.43 & 3.75 & 3.70 & 3.68 \\
Asia & 4.25 & 4.55 & 3.93 & 4.96 & 5.99 \\
South America & 9.68 & 9.67 & 8.96 & 8.98 & 9.47 \\
Africa and Middle East & 21.3 & 21.4 & 20.5 & 20.2 & 21.2 \\
Oceania & 0.89 & 0.85 & 0.76 & 0.85 & 0.95 \\
World & 37.8 & 38.4 & 35.6 & 36.6 & 39.3 \\
\hline
\end{tabular}

land use emissions in Asia.

\section{Discussion and conclusions}

Using the IMAGE integrated assessment model and the global chemistry and transport model TM5, we estimated the impacts of plant exposure to ozone on crop production for the present day (2005) and for three RCP-like scenarios for the first half of the century. Moreover, we have evaluated the subsequent impacts of the corresponding future ozone changes on land use and the carbon cycle. By comparing the different scenarios we have been able to assess possible future impacts of air pollution control and climate change mitigation policy. Some important conclusions can be drawn.

For many crop types the relative yield loss (RYL) and crop production loss (CPL) caused by present-day ozone levels is found to be substantial. According to our calculations the relative yield losses for maize and rice may be reaching $10 \%$ in parts of the Middle East, India and China. These percentages are in line with the results found by Van Dingenen et al. (2009), but may be affected by biases in ozone concentrations in TM5. In Europe and the US, where our estimates are less affected by model biases because of the applied mean bias correction in these regions, we find RYL factors of maximally about $4 \%$ for both maize and rice which is below the estimates of Van Dingenen et al. (2009) and Avnery et al. (2011a).

The associated crop production losses for both maize and rice reaches 5 metric tons $/ \mathrm{km}^{2}$ in Asia, which is similar to the presentday estimate of Van Dingenen et al. (2009). Similarly, we estimate small CPLs in the US and Europe for rice. In the case of maize, our computed CPL $\left(0.5\right.$ metric tons $\left./ \mathrm{km}^{2}\right)$ in the northeastern US is lower than the 5 metric tons $/ \mathrm{km}^{2}$ calculated by Van Dingenen et al. (2009). The differences in the estimated CPL are mainly related to the bias correction applied in this study, and the high maize production assumed in Van Dingenen et al. (2009) for this region compared to that simulated in IMAGE.

Without air pollution and climate policies, increasing ozone precursors emissions could lead to higher crop yield losses. Both air pollution and climate policies could reduce these losses by reducing surface ozone concentrations. If control on air pollution policies is not strengthened, crop yield losses could be considerably higher especially in Asia, where we find up to 20\% losses in 2050 compared to a reference situation without ozone changes. Our results also show that significant yield loss can be avoided by reducing emissions of ozone precursors. This can be achieved through air pollution control measures, as co-benefit of climate mitigation policies or by a combination of both.

Reducing ozone damage leads to increased crop productivity, and, possibilities for reducing cultivated area. This, in turn, could lead to a reduction of emissions associated with land-use change. In the worst-case scenario analysed in this study, future ozone increases will increase the global crop area by $2.5 \%$ and the cumulative net $\mathrm{CO}_{2}$ emissions from land use between 2005 and 2050 by about $3.7 \mathrm{Pg} \mathrm{C}$ or $10.4 \%$ compared to the case without changes in ozone. The ozone induced changes in land use are more substantial in regions where severe ozone crop damage is estimated. This is especially the case in Asia, where we find a $8.9 \%$ expansion of the crop area in 2050 and a $52.4 \%$ increase in the cumulative net $\mathrm{CO}_{2}$ emissions between 2005 and 2050. It should be noted that the implementation of climate mitigation policies by itself may result in an increase in crop area, if a significant contribution of bio-energy forms part of the mitigation portfolio.

In some regions the extra crop production as a result of reduced ozone impacts on yields due to climate mitigation is substantial. For instance, the maize and rice yield gains as a result of lower ozone concentrations could reach $10 \%$ in Asia. For comparison, Easterling et al. (2007) estimate that climate change impacts on the yield of maize and rice could be in the order of $40 \%$ for maize and $20 \%$ for rice for local temperatures increases above $3{ }^{\circ} \mathrm{C}$. Recently, Tai et al. (2014) showed similar to this study that air pollution policies have the potential to partially offset the crop production reduction caused by climate change.

This study provides a first exploration of the effects using relatively simple methods to estimate crop damage. Some limitations of this integrated approach to crop yield loss assessment have already been highlighted in previous studies (Van Dingenen et al., 2009; Avnery et al., 2011a and 2011b). Below we indicate the key limitations of this study.

- Our methodology uses an exposure-based approach which has been widely used to assess ozone damage on crops. However, the applicability of this approach is limited because it does not explicitly account for crucial environmental factors (such as temperature, water availability and plant defence), which are important in evaluating the rate of ozone uptake by plants and the eventual damage. For this reason, a mechanistic flux-based method has been designed in recent years (Emberson et al., 2000; Sitch et al., 2007; Yue and Unger, 2014). In this approach the yield loss is calculated from the flux of ozone through the stomata. This requires information on environmental factors like aerodynamic and boundary layer resistance, which affect the stomatal conductivity and uptake of ozone by plants. Flux-based methods are not suitable for the kind of large-scale assessment of crop losses undertaken in this study because of lack of sufficiently reliable data to characterize plant sensitivities (Avnery et al., 2011a; Van Dingenen et al., 2009). More so, experimental data needed for the computation of ozone stomatal flux are only available for a limited number of crops.

- In this study, we have only accounted for the impacts of future changes in emissions on ozone concentrations, without considering any possible effects of future climate change on ozone. Future changes in climatic factors like temperature, precipitation and changes in the large-scale circulation are likely to also affect surface ozone concentrations. However, in most regions emission changes are the main factor influencing the concentrations of ozone in the troposphere in the first half of the century (Fiore et al., 2012; Young et al., 2013). A further source of uncertainty not accounted for is the effect of climate change on biogenic emissions of ozone precursors.

- Also, we have not considered possible impacts of climate change on growing season, as we use a fixed present-day start and length of the growing season in our calculations of ozone indicators. Changes in the crop calendar is likely to have a small impact on crop production losses and land use on a global scale but might be significant on a local scale (Van Dingenen et al., 2009). Furthermore, we do not model the ozone and $\mathrm{CO}_{2}$ 
interaction in IMAGE but rather simulate the effects of ozone changes on the carbon cycle via crop yield. In reality, the reduction in stomatal conductance that follows elevated atmospheric $\mathrm{CO}_{2}$ concentrations suppresses the ozone effects on plants (see Sitch et al., 2007).

- An additional uncertainty is due to biases in the simulated ground-level ozone concentrations. We therefore applied a bias correction to the model-based ozone indicators in Europe and the US. This tends to reduce the present-day ozone impacts on maize production in the US and Europe by on average $48 \%$ and $26 \%$, respectively. In other regions, our calculation of the present-day ozone impacts on crop production is affected by model biases. The bias correction effect is generally smaller than the bias itself because the present-day bias and future bias partially offset each other, and we expect that errors outside of the US and Europe due to these biases to be similar in size to the US and European errors.

- Finally, we assume no changes in agricultural trade regimes in IMAGE. However, future changes in trade patterns will have impacts on agricultural production and land use. For instance trade liberation will lead to an increase in trade of agricultural products and economic benefits in most parts of the world, but to an increase in environmental pressures (increases in land use) especially in developing exporting regions. Also, the introduction of ozone resistant species or intensification of agricultural practices on current crop land could limit the impacts of ozone on land use.

The limitations mentioned above have little influence on the qualitative conclusions of this study.

\section{Acknowledgements}

This work is part of the research programme 'Feedbacks in the climate system', which is financed by the Netherlands Organisation for Scientific Research (NWO). The authors would like to thank Rita van Dingenen, Håkan Pleijel, Max Posch, and Maurits van den Berg for useful comments.

\section{Appendix A. Supplementary data}

Supplementary data related to this article can be found at http:// dx.doi.org/10.1016/j.atmosenv.2015.01.062.

\section{References}

Aunan, K., Berntsen, T.K., Seip, H.M., 2000. Surface ozone in China and its possible impact on agricultural crop yields. Ambio 29, 294-301.

Averny, S., Mauzerall, D., Liu, J., Horowitz, L.W., 2011a. Global crop yield reductions due to surface ozone exposure: 1. Year 2000 crop production losses and economic damage. Atmos. Environ. 45, 2284-2296.

Averny, S., Mauzerall, D., Liu, J., Horowitz, L.W., 2011b. Global crop yield reductions due to surface ozone exposure: 2. Year 2030 potential crop production losses and economic damage under two scenarios of $\mathrm{O3}$ pollution. Atmos. Environ. 45, 2297-2309.

Avnery, S., Mauzerall, D., Fiore, A.M., 2013. Increasing global agricultural production by reducing ozone damages via methane emission controls and ozone resistance. Glob. Change Biol. 19, 1285-1299.

Bouwman, A.F., Kram, T., Klein-Goldewijk, K., 2006. Integrated Modelling of Global Environmental Change. An Overview of IMAGE 2.4. Netherlands Environmental Assessment Agency (MNP), Bilthoven, The Netherlands.

Chuwah, C.D., van Noije, T., van Vuuren, D.P., Hazeleger, W., Strunk, A., Deetman, S., Mendoza Beltran, A., van Vliet, J., 2013. Implications of alternative assumptions regarding future air pollution control in scenarios similar to the representative concentration Pathways. Atmos. Environ. 79, 787-801.

Ciais, P., Sabine, C., Bala, G., Bopp, L., Brovkin, V., Canadell, J., Chhabra, A., DeFries, R., Galloway, J., Heimann, M., Jones, C., Le Quéré, C., Myneni, R.B., Piao, S., Thornton, P., 2013. Carbon and other biogeochemical cycles. in: climate change 2013: the physical science basis. In: Stocker, T.F., Qin, D., Plattner, G.-K. Tignor, M., Allen, S.K., Boschung, J., Nauels, A., Xia, Y., Bex, V., Midgley, P.M. (Eds.), Contribution of Working Group I to the Fifth Assessment Report of the
Intergovernmental Panel on Climate Change. Cambridge University Press, Cambridge, United Kingdom and New York, NY, USA.

De Bock, M., Op de Beeck, M., De Temmerman, L., Guisez, Y., Ceulemans, R, Vandermeiren, K., 2011. Ozone dose-response relationships for spring oilseed rape and broccoli. Atmos. Environ. 45, 1759-1765.

Easterling, W.E., Aggarwal, P.K., Batima, P., Brander, K.M., Erda, L., Howden, S.M., Kirilenko, A., Morton, J., Soussana, J.-F., Schmidhuber, J., Tubiello, F.N., 2007 Food, fibre and forest products. In: Parry, M.L., Canziani, O.F., Palutikof, J.P., van der Linden, P.J., Hanson, C.E. (Eds.), Climate Change 2007: Impacts, Adaptation and Vulnerability. Contribution of Working Group II to the Fourth Assessment Report of the Intergovernmental Panel on Climate Change. Cambridge University Press, Cambridge, UK, pp. 273-313.

Ellingsen, K., Gauss, M., Van Dingenen, R., Dentener, FJ., Emberson, L., Fiore, A.M. Schultz, M.G., Stevenson, D.S., Ashmore, M.R., Atherton, C.S., Bergmann, D.J., Bey, I., Butler, T., Drevet, J., Eskes, H., Hauglustaine, D.A., Isaksen, I.S.A., Horowitz, L.W., Krol, M., Lamarque, J.F., Lawrence, M.G., van Noije, T., Pyle, J. Rast, S., Rodriguez, J., Savage, N., Strahan, S., Sudo, K., Szopa, S., Wild, O., 2008. Global ozone and air quality: a multi-model assessment of risks to human health and crops. Atmos. Chem. Phys. Discuss. 8, 2163-2223.

Emberson, L.D., Ashmore, M.R., Cambridge, H.M., Simpson, D., Tuovinen, J.-P. 2000. Modelling stomatal ozone flux across Europe. Environ. Pollut. 109, 403-413.

Emberson, L.D., Büker, P., Ashmore, M.R., Mills, G., Jackson, L.S., Agrawal, M., Atikuzzaman, M.D., Cinderby, S., Engardt, M., Jamir, C., Kobayashi, K. Oanh, N.T.K., Quadir, Q.F., Wahid, A., 2009. A comparison of North American and Asian exposure-response data for ozone effects on crop yields. Atmos. Environ. 43, 1945-1953.

Fiore, A.M., Naik, V., Spracklen, D.V., Steiner, A., Unger, N., Prather, M., Bergmann, D. Cameron-Smith, P.J., Cionni, I., Collins, W.J., Dalsøren, S., Eyring, V., Folberth, G.A., Ginoux, P., Horowitz, L.W., Josse, B., Lamarque, J.-F., MacKenzie, I.A., Nagashima, T., O'Connor, F.M., Righi, M., Rumbold, S.T., Shindell, D.T., Skeie, R.B., Sudo, K., Szopa, S., Takemura, T., Zeng, G., 2012. Global air quality and climate. Chem. Soc. Rev. 41, 6663-6683.

Fuhrer, J., Skärby, L., Ashmore, M.R., 1997. Critical levels for ozone effects on vegetation in Europe. Environ. Pollut. 97, 91-106.

Fuhrer, J., 2009. Ozone risk for crops and pastures in present and future climates. Naturwissenschaften 96, 173-194.

Ganzeveld, L., Bouwman, L., Stehfest, E., van Vuuren, D.P., Eickhout, B., Lelieveld, J., 2010. Impact of future land use and land cover changes on atmospheric chemistry-climate interactions. J. Geophys. Res. 115, D23301. http://dx.doi.org/ 10.1029/2010JD014041.

González-Fernández, I., Bass, D., Muntifering, R., Mills, G., Barnes, J., 2008. Impacts of ozone pollution on productivity and forage quality of grass/clover swards. Atmos. Environ. 42, 8755-8769.

Grantz, D., Vu, H., 2009. $\mathrm{O}_{3}$ sensitivity in a potential $\mathrm{C}_{4}$ bioenergy crop: sugarcane in California. Crop Sci. 49, 643-650.

Heck, W.W., Adams, R.M., Cure, W.W., Heagle, A.S., Heggestad, H.E., Kohut, R.J., Kress, L.W., Rawlings, J.O., Taylor, O.C., 1983. A reassessment of crop loss from ozone. Environ. Sci. Technol. 17, 572A-581A.

Huijnen, V., Williams, J., van Weele, M., van Noije, T., Krol, M., Dentener, F., Segers, A., Houweling, S., Peters, W., de Laat, J., Boersma, F., Bergamaschi, P., van Velthoven, P., Le Sager, P., Eskes, H., Alkemade, F., Scheele, R., Nédélec, P., Pätz, H.-W., 2010. The global chemistry transport model TM5: description and evaluation of the tropospheric chemistry version 3.0. Geosci. Model Dev. 3, 445-473.

Karenlampi, L., Skärby, L. (Eds.), 1996. Critical Levels for Ozone in Europe: Testing and Finalizing the Concepts. Department of Ecology and Environmental Science, University of Kuopio. UN-ECE workshop report.

Karlsson, P.E., Braun, S., Broadmeadow, M., Elvira, S., Emberson, L., Gimeno, B.S., Le Thiec, D., Novak, K., Oksanen, E., Schaub, M., Uddling, J., Wilkinson, M., 2007. Risk assessments for forest trees: the performance of the ozone flux versus the AOT concepts. Environ. Pollut. 146, 608-616.

Lathière, J. Hauglustaine, D.A., Friend, A.D., De Noblet-Ducoudré, N., Viovy, N. Folberth, G.A., 2006. Impact of climate variability and land use changes on global biogenic volatile organic compound emissions. Atmos. Chem. Phys. 6 2129-2146.

Mills, G., Buse, A., Gimeno, B., Bermejo, V., Holland, M., Emberson, L., Pleijel, H., 2007. A synthesis of AOT40-based response functions and critical levels of ozone for agricultural and horticultural crops. Atmos. Environ. 41, 2630-2643.

Nakićenović, N., Alcamo, J., Davis, G., de Vries, B., Fenhann, J., Gaffin, S., Gregory, K. Griibler, A., Jung, T.Y., Kram, T., Lebre La Rovere, E., Michaelis, L., Mori, S., Morita, T., Pepper, W., Pitcher, H., Price, L., Riahi, K., Roehrl, A., Rogner, H.-H. Sankovski, A., Schlesinger, M., Shukla, P., Smith, S., Swart, R., van Rooijen, S. Victor, N., Dadi, Z., 2000. Special Report on Emissions Scenarios. A Special Report of Working Group III of the Intergovernmental Panel on Climate Change. Cambridge University Press, Cambridge, United Kingdom and New York, NY, USA, p. 599.

Pleijel, H., Danielsson, H., Vandermeiren, K., Blum, C., Colls, J., Ojanperä, K., 2002. Stomatal conductance and ozone exposure in relation to potato tuber yield results from the European CHIP programme. Eur. J. Agron. 17, 303-317.

Royal Society, 2008. Ground-level Ozone in the $21^{\text {st }}$ Century: Future Trends, Impacts and Policy Implications. The Royal Society, London, p. 132. Policy Document 15/ 08.

Sitch, S., Cox, P.M., Collins, W.J., Huntingford, C., 2007. Indirect radiative forcing of climate change through ozone effects on the land-carbon sink. Nature 448 , $791-795$. 
Tai, A.P.K., Val Martin, M., Heald, C.L., 2014. Threat to future global food security from climate change and ozone air pollution. Nat. Clim. Chang. 4, 817-821.

Van Dingenen, R., Dentener, F.J., Raes, F., Krol, C.K., Emberson, L., Janusz, C., 2009 The global impact of ozone on agricultural crop yields under current and future air quality legislation. Atmos. Environ. 43, 604-618.

Van Noije, T.P.C., Le Sager, P., Segers, A.J., van Velthoven, P.F.J., Krol, M.C., Hazeleger, W., Williams, A.G., Chambers, S.D., 2014. Simulation of tropospheric chemistry and aerosols with the climate model EC-Earth. Geosci. Model Dev. 7 2435-2475.

Van Vuuren, D.P., den Elzen, M.G.J., Lucas, P.L., Eickhout, B., Strengers, B.J., van Ruijven, B., Wonink, S., van Houdt, R., 2007. Stabilizing greenhouse gas concentrations at low levels: an assessment of reduction strategies and costs. Clim. Change 81, 119-159.

Van Vuuren, D.P., Edmonds, J., Kainuma, M., 2011. The representative concentration pathways: an overview. Clim. Change 109, 5-31.

Wang, X., Mauzerall, D.L., 2004. Characterizing distributions of surface ozone and its impact on grain production in China, Japan and South Korea: 1990 and 2020.
Atmos. Environ. 38, 4383-4402.

Wild, O., Prather, M.J., 2006. Global tropospheric ozone modeling: quantifying errors due to grid resolution. J. Geophys. Res. 111, D08301. http://dx.doi.org/ 10.1029/2005JD006338.

Wu, S., Mickley, L.J., Kaplan, J.O., Jacob, D.J., 2012. Impacts of changes in land use and land cover on atmospheric chemistry and air quality over the $21^{\text {st }}$ century. Atmos. Environ. 12, 1597-1609.

Young, P.J., Archibald, A.T., Bowman, K.W., Lamarque, J.-F., Naik, V., Stevenson, D.S., Tilmes, S., Voulgarakis, A., Wild, O., Bergmann, D., Cameron-Smith, P., Cionni, I., Collins, W.J., Dalsøren, S.B., Doherty, R.M., Eyring, V., Faluvegi, G., Horowitz, L.W., Josse, B., Lee, Y.H., MacKenzie, I.A., Nagashima, T., Plummer, D.A., Righi, M., Rumbold, S.T., Skeie, R.B., Shindell, D.T., Strode, S.A., Sudo, K., Szopa, S. Zeng, G., 2013. Pre-industrial to end 21st century projections of tropospheric ozone from the atmospheric chemistry and climate model intercomparison project (ACCMIP). Atmos. Chem. Phys. 13, 2063-2090.

Yue, X. Unger, N., 2014. Ozone vegetation damage effects on gross primary productivity in the United States. Atmos. Chem. Phys. 14, 9137-9153. 